\title{
Gut hormone release after intestinal resection
}

\author{
H S BESTERMAN, ${ }^{*}$ T E ADRIAN, C N MALLINSON, $\dagger \mathrm{N}$ D CHRISTOFIDES, \\ D L SARSON, A PERA, L LOMBARDO, R MODIGLIANI, and S R BLOOM
}

From the Department of Medicine, Royal Postgraduate Medical School, Hammersmith Hospital, London, Division of Gastroenterology, Ospedale Mauriziano, Turin, Italy, Gastrointestinal Unit, Greenwich District Hospital, London, and Hôpital St Lazare, Paris, France

SUMmARY To investigate the possible role of gut and pancreatic hormones in the adaptive responses to gut resection, plasma concentrations of the circulating hormones were measured, in response to a test breakfast, in patients with either small or large intestinal resection and in healthy control subjects. In 18 patients with partial ileal resection a significant threefold rise was found in basal and postprandial levels of pancreatic polypeptide, a fourfold increase in motilin, and more than a twofold increase in gastrin and enteroglucagon levels compared with healthy controls. In contrast, nine patients with colonic resection had a threefold rise in levels of pancreatic polypeptide only. One or more of these peptides may have a role in stimulating the adaptive changes found after gut resection.

After small intestinal resection, there are two widely reported alterations in morphology and physiology. There is villous hyperplasia of the remaining small intestine $^{1-3}$ with an equivalent functional compensation. This presumably represents an adaptive process to compensate for the diminished absorptive surface area after resection. ${ }^{46}$ These adaptive responses are much more marked in the ileum after proximal small intestinal resection, but are also reported to occur in the jejunum after distal small bowel resection, albeit to a lesser extent ${ }^{78}$ and also in the colon. ${ }^{10}$ The mechanism of this process may well be humorally mediated ${ }^{11-14}$ and a number of gastrointestinal hormones have trophic actions. ${ }^{15-17}$

In addition, gastric hypersecretion has been reported in these patients ${ }^{18} 19$ which may be due either to loss of an inhibitory factor present in the ileum ${ }^{20}{ }^{21}$ to decreased degradation of gastrin or to hypersecretion of gastrin. ${ }^{22}$ The gastric hypersecretion in patients who have undergone ileal resection for Crohn's disease relates to their surgery and not to any remaining disease activity. ${ }^{23}$ These and other possible mechanisms are discussed in a recent review. ${ }^{22}$

\footnotetext{
* Present address: Departments of Medicine and Endocrinology, St Bartholomew's Hospital, London EC1.

+ Present address: Department of Medicine, Lewisham Hospital, London SE13.

Received for publication 29 January 1982
}

In order to elucidate whether gut hormones might be implicated in any of these alterations, we have measured the circulating plasma concentrations of several gut hormones before and after a standard test breakfast in patients with resection of the small and large intestine and in age- and sex-matched healthy controls.

\section{Methods}

\section{PATIENTS}

Permission for these studies was obtained from the Ethical Committees at each of the participating centres and informed consent was given by all subjects tested.

\section{SMALL INTESTINAL RESECTION}

Eighteen patients (10 men, eight women) had previously undergone partial resection of the ileum. Their mean age was 48 years (range 20-72 years) and their mean weight was $54 \pm 3 \cdot 3(\mathrm{x} \pm \mathrm{SEM}) \mathrm{kg}$, which corresponded to $90 \pm 4 \%$ of ideal.

In 13 patients the underlying indication for surgery was Crohn's disease. All of these had had from 0.4 to $2 \mathrm{~m}$ of distal ileum resected. Two patients had radiation-induced fibrosis necessitating resection of all but $1 \mathrm{~m}$ of distal ileum. Another patient needed resection of $1 \mathrm{~m}$ of terminal ileum for ischaemic necrosis after volvulus. Another patient had all his small intestine resected except for $5 \mathrm{~cm}$ of distal ileum and $30 \mathrm{~cm}$ of jejunum after trauma. ${ }^{24}$ 
The median time of study from operation was three years with a range of one month to 24 years. The median number of bowel frequencies per day was four with a range of one to 20 .

\section{LARGE INTESTINAL RESECTION}

Nine patients (four men, five women) had previously undergone total or partial colectomy. Their mean age was 34 years (range 21-62 years) with a mean weight of $53 \pm 4 \mathrm{~kg}(\mathrm{x} \pm \mathrm{SEM})$ which corresponded to $91 \pm 6 \%$ of ideal.

All but one of the patients underwent colectomy for inflammatory bowel disease (two with ulcerative colitis, six with Crohn's disease). The other case underwent resection of his sigmoid colon for carcinoma and diverticular disease. The extent of resection of the other cases varied between total proctocolectomy to right hemicolectomy. The median time from operation to study was $2 \frac{1}{2}$ years with a range of six months to eight years. The median number of bowel frequencies per day in five patients was five with a range of one to eight. The other four patients had ileostomies.

\section{NORMAL SUBJECTS}

Eleven healthy subjects (six men, five women) acted as normal controls. They had a mean age of 43 years

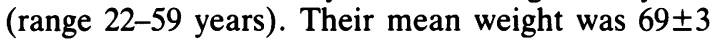
$\mathrm{kg}(\mathrm{x} \pm \mathrm{SEM})$ corresponding to $107 \pm 2 \%$ ideal. None had either present or past history of gastrointestinal or other significant illness. The median bowel frequency was one per day and ranged from every other day to twice a day.

\section{TEST BREAKFAST}

All subjects were fasted overnight and blood samples were taken before and for three hours after the standard breakfast. This consisted of two medium-sized boiled eggs, $60 \mathrm{~g}$ bread as toast, $10 \mathrm{~g}$ butter, $35 \mathrm{~g}$ marmalade, and $150 \mathrm{ml}$ unsweetened orange juice. The breakfast contained $18 \mathrm{~g}$ protein, $22 \mathrm{~g}$ fat, and $66 \mathrm{~g}$ carbohydrate, equivalent to 530 Calories $(2225 \mathrm{KJ})$.

Blood samples for hormone assays were taken into heparinised tubes and 400 Kallikrein-inhibitory units of aprotinin (Trasylol) per $\mathrm{ml}$ were added. Plasma was separated within 15 minutes of sampling and stored at $-20^{\circ} \mathrm{C}$ until assay.

\section{TECHNIQUES}

Blood glucose estimation was carried out using standard glucose oxidase/peroxidase methodology as adapted for the autoanalyser. ${ }^{25}$ Plasma hormone concentrations were measured by specific radioimmunoassays, which have previously been described in detail, and were carried out by conventional methods with antisera raised to pure natural gastrin, ${ }^{26}$ pancreatic polypeptide, ${ }^{27}$ and insulin ${ }^{28}$ to pure porcine gastric inhibitory polypeptide (GIP) ${ }^{29}$ and motilin, ${ }^{30}$ and to natural bovine neurotensin. ${ }^{31}$ Glucagon was measured using two separate systems, one using a C-terminal reacting antibody specific for pancreatic glucagon, ${ }^{32}$ and a second reacting with the mid to $\mathrm{N}$-terminal sequence of glucagon which also measured gut glucagon immunoreactivity and which showed complete cross-reactivity with porcine glicentin. ${ }^{33}$ Enteroglucagon was derived by substraction of the specific pancreatic glucagon values from those obtained using the $\mathrm{N}$-terminal glucagon assay. The assays were capable of detecting the following plasma changes with $95 \%$ confidence: gastrin $2 \mathrm{pmol} / \mathrm{l}$, pancreatic polypeptide $4 \mathrm{pmol} / \mathrm{l}$, GIP $3 \mathrm{pmol} / \mathrm{l}$, enteroglucagon $10 \mathrm{pmol} / \mathrm{l}$, and insulin $6 \mathrm{pmol} / \mathrm{l}$. Statistical analysis was made

Table Results of patients in two resection groups and normal controls (mean $\pm S E M$ )

\begin{tabular}{|c|c|c|c|c|c|c|c|c|c|}
\hline & $\begin{array}{l}\text { Blood } \\
\text { glucose } \\
\text { (mmol/l) }\end{array}$ & $\begin{array}{l}\text { Insulin } \\
(\mathrm{pmol} / \mathrm{l})\end{array}$ & $\begin{array}{l}G I P \\
(p m o l / l)\end{array}$ & $\begin{array}{l}\text { Gastrin } \\
(\mathrm{pmol} / \mathrm{l})\end{array}$ & $\begin{array}{l}H P P \\
(p m o l / l)\end{array}$ & $\begin{array}{l}\text { Pancreatic } \\
\text { glucagon } \\
\text { (pmol/l) }\end{array}$ & $\begin{array}{l}\text { Motilin } \\
(\mathrm{pmol} / \mathrm{l})\end{array}$ & $\begin{array}{l}\text { Entero- } \\
\text { glucagon } \\
\text { (pmolll) }\end{array}$ & $\begin{array}{l}\text { Neuro- } \\
\text { tensin } \\
(p m o l / l)\end{array}$ \\
\hline \multicolumn{10}{|c|}{ Normal subjects } \\
\hline Basal & $4 \cdot 2 \pm 0 \cdot 2$ & $33 \pm 4$ & $9 \pm 1$ & $5 \pm 0 \cdot 5$ & $15 \pm 3$ & $9 \pm 2$ & $63 \pm 8$ & $32 \pm 7$ & $50 \pm 6$ \\
\hline Peak rise & $1 \cdot 6 \pm 0 \cdot 3$ & $240 \pm 36$ & $33 \pm 7$ & $17 \pm 4$ & $116 \pm 19$ & $3 \pm 2$ & $16 \pm 6$ & $26 \pm 7$ & $22 \pm 3$ \\
\hline TIR & $843 \pm 49$ & $24 \cdot 6 \pm 2 \cdot 8$ & $6 \cdot 8 \pm 1 \cdot 8$ & $2 \cdot 6 \pm 0 \cdot 2$ & $15 \cdot 5 \pm 2 \cdot 6$ & $1 \cdot 4 \pm 0 \cdot 2$ & $10 \cdot 2 \pm 1 \cdot 9$ & $8 \cdot 3 \pm 1 \cdot 1$ & $11 \cdot 0 \pm 1 \cdot 3$ \\
\hline \multicolumn{10}{|l|}{ SI resection } \\
\hline Basal & $4 \cdot 3 \pm 0 \cdot 2$ & $26 \pm 3$ & $13 \pm 2 \cdot 0$ & $13 \pm 2+$ & $60 \pm 21^{*}$ & $7 \pm 2$ & $196 \pm 46^{*}$ & $64 \pm 11^{*}$ & $41 \pm 3$ \\
\hline Peak rise & $1 \cdot 7 \pm 0 \cdot 3$ & $222 \pm 37$ & $49 \pm 10$ & $43 \pm 10^{*}$ & $271 \pm 32$ ף & $4 \pm 1$ & $117 \pm 29 \S$ & $64 \pm 16^{*}$ & $23 \pm 3$ \\
\hline TIR & $898 \pm 73$ & $24 \cdot 3 \pm 3 \cdot 3$ & $8 \cdot 1 \pm 1 \cdot 2$ & $6 \cdot 1 \pm 1 \cdot 3+$ & $42 \cdot 9 \pm 7 \cdot 3 \S$ & $1 \cdot 2 \pm 0 \cdot 2$ & $43 \cdot 7 \pm 11 \ddagger$ & $19 \cdot 1 \pm 3 \cdot 1 \S$ & $9 \cdot 6 \pm 0 \cdot 8$ \\
\hline \multicolumn{10}{|l|}{ LI resection } \\
\hline Basal & $4 \cdot 1 \pm 0 \cdot 2$ & $26 \pm 3$ & $12 \pm 2 \cdot 0$ & $10 \pm 4$ & $39 \pm 9+$ & $7 \pm 1$ & $56 \pm 14$ & $16 \pm 5 \cdot 5$ & $38 \pm 9$ \\
\hline Peak rise & $1 \cdot 8 \pm 0 \cdot 3$ & $197 \pm 36$ & $43 \pm 8$ & $29 \pm 8 \ddagger$ & $284 \pm 53 \ddagger$ & $3 \pm 1$ & $57 \pm 26$ & $27 \pm 5$ & $26 \pm 6$ \\
\hline TIR & $928 \pm 63$ & $22 \cdot 3 \pm 4 \cdot 2$ & $7 \cdot 6 \pm 1 \cdot 2$ & $5 \cdot 0 \pm 1 \cdot 8$ & $39 \cdot 5 \pm 8 \cdot 9+$ & $1 \cdot 2 \pm 0 \cdot 2$ & $15 \cdot 8 \pm 5 \cdot 3$ & $5 \cdot 8 \pm 1 \cdot 0$ & $9 \cdot 9 \pm 1 \cdot 2$ \\
\hline
\end{tabular}

Statistical significance vs normal subjects: ${ }^{*} \mathrm{p}<0 \cdot 05 .+\mathrm{p}<0 \cdot 02 . \neq \mathrm{p}<0 \cdot 01 . \S \mathrm{p}<0 \cdot 005 . \rrbracket \mathrm{p}<0 \cdot 001$.

TIR expressed as nmol. $\mathrm{I}^{-1} .180 \mathrm{~min}^{-1}$ except for glucose $-\mathrm{mmol} . \mathrm{I}^{-1} .180 \mathrm{~min}^{-1}$. 


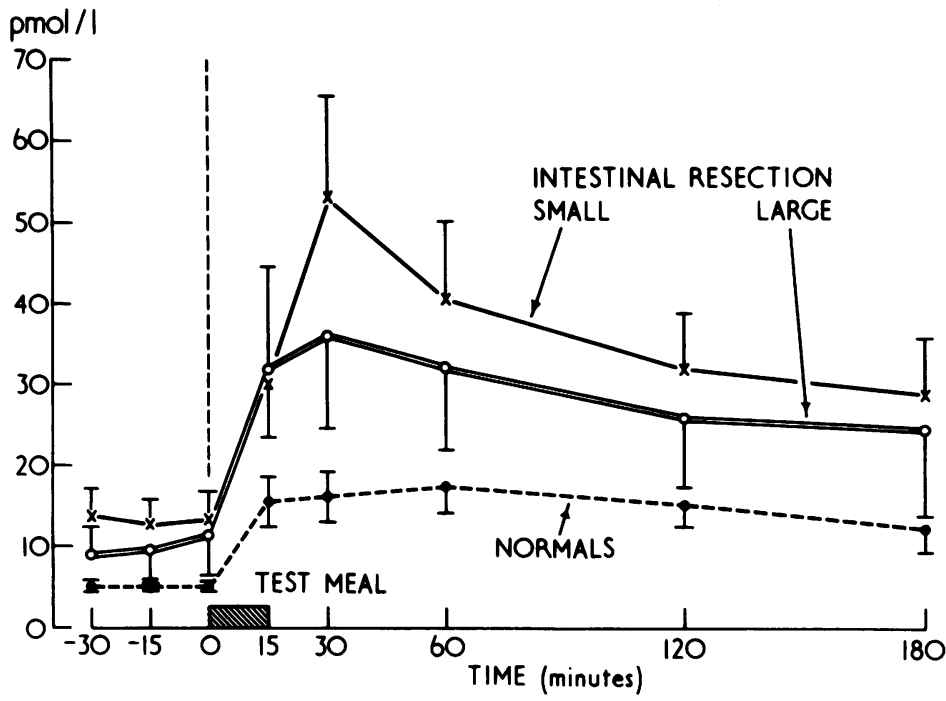

Fig. 1 Plasma gastrin responses (mean $\pm S E M$ ) to a test meal in 11 normal subjects and in 18 patients with small and in nine patients with large intestinal resection. using Student's $t$ test for unpaired data for parameters with normal distribution and using non-parametric (Whitney Mann U test) methodology for parameters with a known skewed distribution.

\section{Results}

Mean fasting levels, peak postprandial rises, and total integrated responses for blood glucose and gut hormones for both groups of intestinal resection patients and in healthy controls are shown in the Table.
GASTRIN (Fig. 1)

Patients with partial ileal resection had significantly raised fasting levels, peak postprandial rises, and total integrated responses of plasma gastrin compared with healthy controls. Patients with large intestinal resection had plasma gastrin levels which, although slightly raised, were not significantly different from normal subjects. In addition, no correlation was found between gastrin levels and the extent of colonic resection.

PANCREATIC POLYPEPTIDE (Fig. 2)

Both groups of patients with gut resection had
Fig. 2 Plasma human pancreatic polypeptide responses (mean $\pm S E M)$ to a test meal in 11 normal subjects and in 18 patients with small and in nine patients with large intestinal resection.

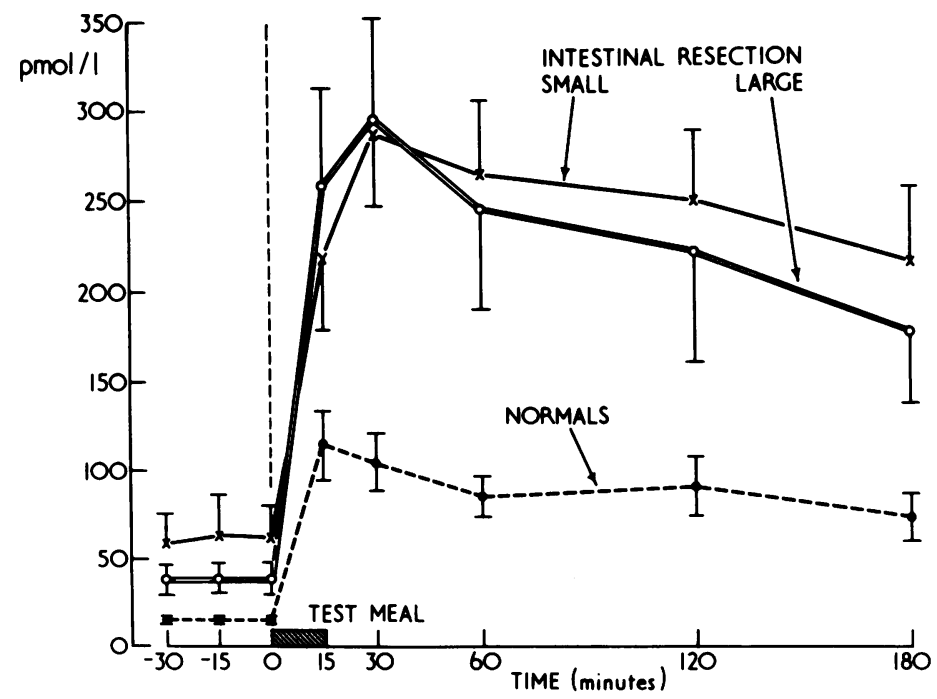




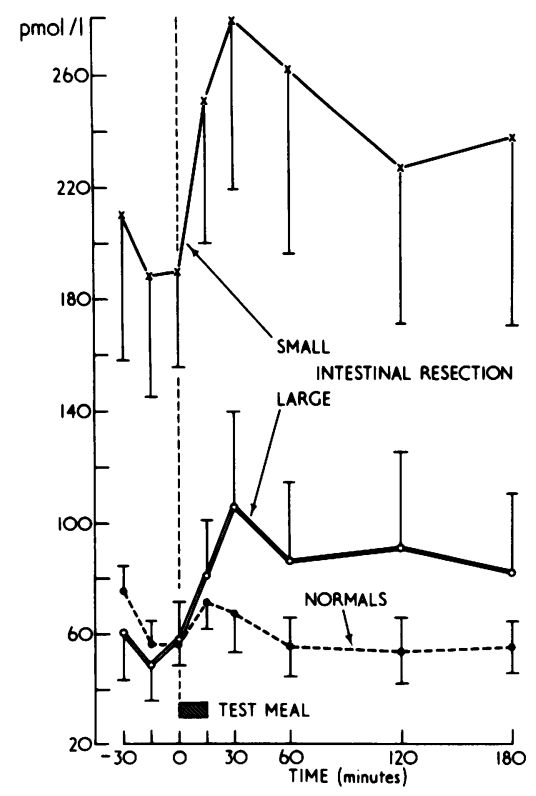

Fig. 3 Plasma motilin responses (mean $\pm S E M$ ) to a test meal in 11 normal subjects and in 18 patients with small and in nine patients with large intestinal resection.

significantly raised fasting and postprandial plasma pancreatic polypeptide levels compared with control subjects.

\section{MOTILIN (Fig. 3)}

Patients with partial ileal resection had significantly raised basal levels, postprandial rises, and total integrated responses of plasma motilin. The group with colonic resection, however, had fasting plasma motilin levels which were similar to controls and an augmented postprandial response but this failed to reach statistical significance.

\section{ENTEROGLUCAGON (Fig. 4)}

Fasting plasma enteroglucagon levels, peak postprandial rises, and total integrated responses after the meal were all significantly greater than normal in the group with partial ileal resection. The group with colonic resection, however, had plasma enteroglucagon levels which were lower than control values but the difference did not reach statistical significance.

BLOOD GLUCOSE, INSULIN, GIP, PANCREATIC GLUCAGON, AND NEUROTENSIN

There was no significant difference from normal in fasting or postprandial plasma levels or in total integrated responses of blood glucose, insulin, GIP, pancreatic glucagon or in neurotensin in either group of patients with gut resection.

There was no correlation between any of the peptides measured and the length of time since resection, the length of gut resected, or the frequency of bowel habit with the exception of pancreatic polypeptide, where there was a significant positive correlation of bowel frequency with individual total integrated responses in patients with small intestinal resection $(r=0 \cdot 59, \mathrm{p}<0 \cdot 01)$.

\section{Discussion}

All the patients in this study had macroscopically normal proximal small intestines at operation apart from the two patients with massive resection of ileum and jejunum. In all but these two patients the plasma levels of glucose, insulin, pancreatic glucagon, and GIP were within normal limits after a standard meal. This confirms previous reports for glucose and insulin in man,${ }^{34}$ for GIP in Rhesus monkeys ${ }^{35}$ and for insulin and pancreatic glucagon in dogs. ${ }^{36}$ Impaired glucose tolerance but with normal insulin release after oral glucose has been reported to occur short-term (four to five weeks) after distal resection. ${ }^{34}$ In another series, 13 patients were studied after massive small intestinal resection, seven of whom had jejunal resection as well as ileal.

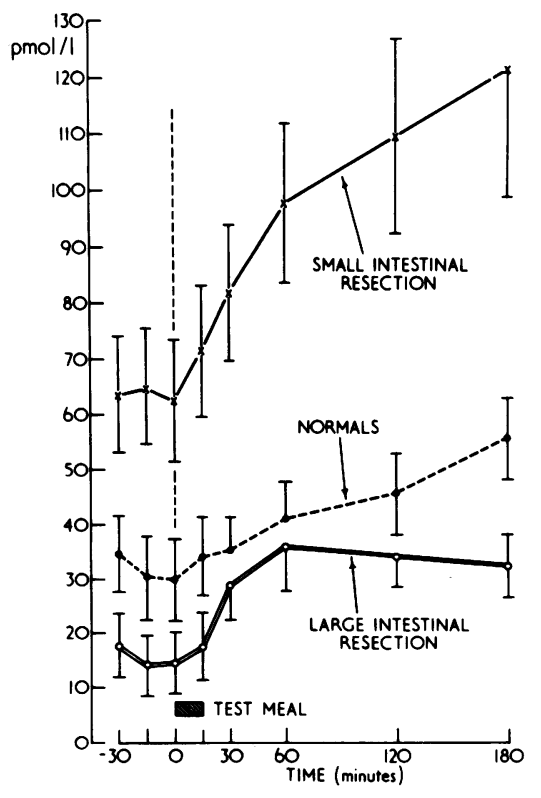

Fig. 4 Plasma enteroglucagon responses (mean $\pm S E M$ ) to a test meal in 11 normal subjects and in 18 patients with small and in nine patients with large intestinal resection. 
These patients had diminished insulin responses to oral glucose in both the short and long term. ${ }^{37}$ They attributed the differences in findings to differences in the patients studied and the extent of small intestinal resection. These patients, however, like ours, had normal fasting levels of pancreatic glucagon with normal responses of both insulin and glucagon to intravenous arginine. These findings are consistent with the belief that the enteric site of the entero-insular axis resides in the duodenum and jejunum. In contrast patients with intact but diseased small bowel due to coeliac disease or tropical malabsorption have an impaired enteroinsular response to the same stimulus. ${ }^{38} 39$

There is good evidence that a compensatory increase in cell number ${ }^{40} 41$ and absorptive function occurs in the ileum after resection of the jejunum and also, to a lesser extent, in the upper small intestine after ileal resection. Small intestinal adaptation has also been reported to occur after colectomy. ${ }^{42}$ It has further been demonstrated that the increase in ileal mucosal mass is related to loss of colon itself and is not secondary to any increase in ileal nutrition or loss of fluid and electrolytes. ${ }^{43}$ These adaptive responses have been attributed to the alteration of intraluminal content but there is also persuasive evidence that adaptation is also mediated by humoral mechanisms. Thus, small bowel, either transplanted within an animal after resection, ${ }^{44-46}$ or in animals parabiotically fed from resected animals, ${ }^{11} 4748$ undergoes adaptation in the absence of increased luminal nutrition. Enteroglucagon is a strong contestant for such a humoral factor. Thus circumstantial evidence, which includes data from the only reported secretory tumour of enteroglucagon ${ }^{49}$ and other work, ${ }^{50}$ suggests that this hormone is trophic to small intestinal mucosa including the jejunum. In rats, the intestinal response to starvation can be prevented by prior administration of glucagon-binding antibodies. ${ }^{51}$ It is likely that this effect is mediated by interaction of these antibodies with enteroglucagon rather than pancreatic glucagon, as exogenous glucagon has been shown to reduce villous height and cell migration in rat enteric mucosa. ${ }^{52}$ In an earlier, preliminary report in rats, raised enteroglucagon levels were found after both proximal and distal enteric resection. This was associated with hyperplasia of the enteroglucagon-containing cells and also with an increase in the enteroglucagon cell to enterocyte ratio. ${ }^{53}$ It is interesting that ileal resection is followed by an increase in plasma levels of enteroglucagon as the ileum is the richest site of enteroglucagon cells in the gut. ${ }^{33}$ No correlation, however, was found between the length of ileum resected and circulating plasma enteroglucagon levels. Three patients could be classified as having massive small intestinal resection. One patient, with all but $70 \mathrm{~cm}$ of ileum resected for radiation-induced fibrosis had enteroglucagon levels which were slightly greater than the mean for the group. The second patient, who had had all his small intestine resected except for $4 \mathrm{~cm}$ of ileum and $10 \mathrm{~cm}$ of jejunum for traumatic infarction, ${ }^{24}$ had very low levels of enteroglucagon. The third patient, who had his entire ileum and all but $60 \mathrm{~cm}$ of jejunum resected for leiomyosarcoma had fasting enteroglucagon levels which were only just below the mean for the entire group. From this small number of patients it would seem that only if virtually the entire small intestine is resected do basal and postprandial enteroglucagon levels fail to rise. The remaining jejunum or ileum, along with the colon, must still be able to hypersecrete enteroglucagon despite resection of a large proportion of enteroglucagon-containing small bowel. In dogs with extensive distal small bowel resection no difference from control animals was found in fasting or stimulated enteroglucagon. ${ }^{54}$ There was no failure of release despite massive resection and the lack of rasied levels may be due to the extent of the resection, as in our second patient, or to species differences. Ileal mucosal hyperplasia has been described after colonic resection in the rat ${ }^{42} 4355-57$ and man. ${ }^{58}$ The colectomy patients had reduced basal levels but normal postprandial responses of enteroglucagon, although the reason for this is not apparent. No correlation was found between the length of colon resected and either basal or postprandial enteroglucagon responses. Thus, in our patients with colonic resection, if mucosal hyperplasia occurred, it was not expressed in an increase in plasma enteroglucagon levels, at least not during a test meal.

The great majority of patients studied had inflammatory bowel disease as the indication for gut resection. We found in unoperated patients with both Crohn's disease and ulcerative colitis only a slight rise in fasting enteroglucagon levels with only a very small postprandial rise. ${ }^{59} \mathrm{We}$ feel, therefore, that the striking rise in plasma enteroglucagon levels seen in patients with small intestinal resection reflects the effect of their surgery rather than the underlying pathological state.

The modest increases in plasma gastrin seen in these patients is consistent with previous reports. $^{21} 36$ The levels found are well within the physiological range, however, and these concentrations are known to be without effect on small bowel mucosal growth and are well below the levels induced by pharmacological gastrin and pentagastrin administration which have been found to 
induce hyperplasia in the duodenum but not in the remaining small bowel. ${ }^{60}$ Furthermore, massive endogenous hypergastrinaemia, as in achlohydria, does not produce any significant alteration in small intestinal structure or function. ${ }^{61}$ There is increasing evidence that gastrin is unlikely to be the mediator of intestinal adaption after intestinal resection. ${ }^{62} 63$

Motilin, a peptide localised in the upper small intestine has recently been shown to exert a powerful effect on both small and large intestine. ${ }^{64}$ Plasma motilin has previously been found to be raised in several conditions accompanied by diarrhoea but, so far, it has not been clear whether this is a primary or secondary event. ${ }^{65}$ It is interesting, therefore, that motilin was raised regardless of whether patients complained of diarrhoea or not. Thus, it seems to be a direct response to ileal resection rather than to alteration of bowel habit. The rise of pancreatic polypeptide in both groups of patients is unexplained. The main physiological effects of this enigmatic hormone are to reduce gallbladder contraction ${ }^{66}$ and pancreatic enzyme secretion ${ }^{67} 68$ and to stimulate water absorption in the distal small intestine. ${ }^{69}$ In addition, low doses of pancreatic polypeptide reduced motility in both small and large intestine of the dog. ${ }^{70}$ An increase in intestinal absorptive capacity and alteration in motility could be seen as adaptive mechanisms in patients with ileal or colonic resection.

After gut resection there follows a compensatory adaption of the remaining intestine. There is good evidence that these changes are humorally mediated. We have found that patients with ileal resection have significantly raised plasma levels of gastrin, motilin, pancreatic polypeptide, and enteroglucagon. These peptides may possibly represent the circulating mediators of such adaptive responses. It would, therefore, be of great interest to follow up these findings with further studies correlating intestinal histology, mucosal cell kinetics, absorptive function, and circulating gut hormones in patients with intestinal resection.

This work was financed by the Wellcome Trust, the British Diabetic Association and the Institut National de la Santé et de la Rechèrche Medicale. We thank Professor C C Booth, Dr V S Chadwick, Dr T J Peters, Professor J J Bernier, and Professor $\mathrm{G}$ Verme for allowing us to study their patients.

\section{References}

1 Porus RL. Epithelial hyperplasia following massive small bowel resection in man. Gastroenterology 1965; 48: 753-7.

2 Weser E, Hernandez MH. Studies of small bowel adaptation after intestinal resection in the rat. Gastroenterology 1971; 60: 69-75.

3 Dowling $\mathrm{RH}$, Gleeson $\mathrm{MH}$. Cell turnover following small bowel resection and bypass. Digestion 1973; 8: 176-90.

4 Althausen TL, Doig RK, Uyeyama K, Weiden S. Digestion and absorption after massive resection of the small intestine. Recovery of the absorptive function as shown by intestinal absorption tests in two patients and a consideration of compensatory mechanisms. Gastroenterology 1950; 16: 126-39.

5 Dowling $\mathrm{RH}$, Booth $\mathrm{CC}$. Functional compensation after small bowel resection in man: demonstration by direct measurement. Lancet 1966; 2: 146-7.

6 Weinstein LD, Shoemaker CP, Hersh T, Wright HK. Enhanced intestinal absorption after small bowel resection in man. Arch Surg 1969; 99: 560-2.

7 Booth CC, Evans KT, Menzies T, Street DF. Intestinal hypertrophy following partial resection of the small bowel in the rat. Br J Surg 1959; 46: 403-10.

8 Dowling RH, Booth CC. Structural and functional changes following small intestinal resection in the rat. Clin Sci 1967; 32: 139-49.

9 Nundy S, Malamud D, Obertop H, Sczerban J, Malt RA. Onset of cell proliferation in the shortened gut. Colonic hyperplasia after ileal resection. Gastroenterology 1977; 72: 263-6.

10 Tilson MD, Livstone EM. Early proliferative activity its occurrence in the crypts of small bowel and colon after partial small-bowel resection. Arch Surg 1980; 115: $1481-5$.

11 Williamson RCN, Bucholtz TW, Malt RA. Humoral stimulation of cell proliferation in small bowel after transection and resection in rats. Gastroenterology 1978; 75: 249-54.

12 Williamson RCN. Intestinal adaptation. Part 1 . Structural, functional and cytokinetic changes. Part 2. Mechanisms of control. N Engl Med J 1978; 298: 1393-1402. 298: 1444-50.

13 Feldman EJ, Carter D, Grossman MI. Intestinal adaptation: evidence for a non-luminal factor which stimulates mucosal growth in dog. Gastroenterology 1978; 74: 1033.

14 Urban E, Weser E. Intestinal adaptation to bowel resection. Adv Intern Med 1980; 26: 265-91.

15 Barrowman JA. The trophic action of gastrointestinal hormones. Digestion 1975; 12: 92-104.

16 Johnson LR. The trophic action of gastrointestinal hormones. Gastroenterology 1976; 70: 278-88.

17 Enochs MR, Johnson LR. Trophic effects of gastrointestinal hormones: physiological implications. Fed Proc 1977; 36: 1942-7.

18 Frederick PL, Sizer JS, Osborne MP. Relation of massive bowel resection to gastric secretion. $N$ Engl J Med 1965; 272: 509-14.

19 Windsor CWO, Fejfar J, Woodward DAK. Gastric secretion after massive small bowel resection. Gut 1969; 10: 779-86.

20 Osborne MP, Frederick PL, Sizer JS, Blair D, Cole P, 
Thum W. Mechanism of gastric hypersecretion following massive intestinal resection: clinical and experimental observations. Ann Surg 1966; 164: 62234.

21 Straus E, Gerson CD, Yalow RS. Hypersecretion of gastrin associated with the short bowel syndrome. Gastroenterology 1974; 66: 175-80.

22 Buxton B. Small bowel resection and gastric acid hypersecretion. Gut 1974; 15: 229-38.

23 Fielding JF, Cooke WT, Williams JA. Gastric acid secretion in Crohn's disease in relation to disease activity and bowel resection. Lancet 1971; 1: 1106-7.

24 Mallinson CN, Merivale WHH. Survival in good health for 21 years after removal of all but eighteen inches of the small intestine. Guy's Hosp Rep 1973; 122: 269-98.

25 Gutteridge JMC, Wright EB. A simple automated guaiacum glucose oxidase method. J Med Lab Technol 1968; 25: 385-6.

26 Russell RCG, Bloom SR, Fielding LP, Bryant MG. Current problems in the measurement of gastrin release. A reproducible measure of physiological gastrin release. Postgrad Med J 1976; 52: 645-50.

27 Adrian TE, Bloom SR, Bryant MG, Polak JM, Heitz $\mathrm{Ph}$, Barnes AJ. Distribution and release of human pancreatic polypeptide. Gut 1976; 17: 940-4.

28 Albano JDM, Ekins RP, Maritz G, Turner RC. A sensitive precise radioimmunoassay of serum insulin relying on charcoal separation of bound and free hormone moieties. Acta Endocrinol 1972; 70: 487-509.

29 Sarson DL, Bryant MG, Bloom SR. A radioimmunoassay of gastric inhibitory polypeptide in human plasma. J Endocrinol 1980; 85: 487-96.

30 Bloom SR, Mitznegg P, Bryant MG. Measurement of human plasma motilin. Scand J Gastroenterol 1976; 11: suppl 39: 47-52.

31 Blackburn AM, Bloom SR. A radioimmunoassay for neurotensin in human plasma. $J$ Endocrinol 1979; 83: 175-81.

32 Alford FP, Bloom SR, Nabarro JDN. Glucagon levels in normal and diabetic subjects: use of a specific immunoabsorbent for glucagon radioimmunoassay. Diabetologia 1977; 13: 1-6.

33 Ghatei MA, Bloom SR. Enteroglucagon in man. In: Bloom SR, Polak JM, eds. Gut hormones vol 2. Edinburgh: Churchill Livingstone, 1981: 332-8.

34 Wapnick S, Jones JJ. Changes in glucose tolerance and serum insulin following partial gastrectomy and intestinal resection. Gut 1972; 13: 871-3.

35 Hall AW, Moossa AR, Wood RAB, Block GE, Skinner DB. Effect of antrectomy on gastric hypersecretion induced by distal small bowel resection. Ann Surg 1977; 186: 83-7.

36 Barros D'Sa AAB, Buchanan KD. Role of gastrointestinal hormones in the response to massive resection of the small bowel. Gut 1979; 18: 877-81.

37 Kajiwara T, Suzuki T, Tobe T. Effect of massive bowel resection on enteroinsular axis. Gut 1979; 20: 806-10.

38 Besterman HS, Bloom SR, Sarson DL et al. Gut hormone profile in coeliac disease. Lancet 1978; 1: 785-8.

39 Besterman HS, Cooke GC, Sarson DL et al. Gut hormones in tropical malabsorption. $\mathrm{Br}$ Med J 1979; 2:
1253-5.

40 Loran MR, Crocker TT. Population dynamics of intestinal epithelia in the rat two months after partial resection of the ileum. J Cell Biol 1963; 19: 285-91.

41 Fenyo G. Morphological changes of the adapting small intestine under various conditions. Acta Clin Scand 1976; 469: suppl: 1-30.

42 Woo ZH, Nygaard K. Small bowel adaptation after colectomy in rats. Scand J Gastroenterol 1978; 13: 903-10.

43 Passeri D, Wright HK, Kricker M. Mechanism of increased ileal structure and function after colectomy. Surg Forum 1979; 30: 373.

44 Tilson MD, Wright HK. Adptation of functioning and bypassed segments of ileum during compensatory hypertrophy of the gut. Surgery 1970; 67: 687-93.

45 Tilson MD, Livstone EM. Radioautography of heterotopic autografts of ileal mucosa in rats after partial enterectomy. Surg Forum 1975; 26: 393-4.

46 Williamson RCN, Bauer FLR. Evidence for enterotropic hormone: compensatory hyperplasia in defunctioned bowel. Br J Surg 1978; 65: 736-9.

47 Loran MR, Carbone JV. The humoral effect of intestinal resection on cellular proliferation and maturation in parabiotic rats. In: Sullivan MF, ed. Gastrointestinal radiation injury. Amsterdam: Excerpta Medica, 1968: 127-39.

48 Laplace JP. Sur l'existence éventuelle d'un facteur circulant, intervenant dans le déterminisime de l'augmentation pondérale du tissu intestinal restant après une résection limitée d'intestin grêle. Etude chez le porcelet par circulation sanguine croisée. Rec Méd Vét 1972; 148: 931-47.

49 Bloom SR. An enteroglucagon tumour. Gut 1972; 13: 520-3.

50 Jacobs LR, Bloom SR, Harsoulis P. Intestinal adaption in hypothermic hyperphagia. Clin Sci Med 1975; 48: $14 \mathrm{p}$.

51 Rudo ND, Lawrence AM, Rosenberg IH. Treatment with glucagon-binding antibodies alters the intestinal response to starvation in the rat. Gastroenterology 1975; 69: 1265-8.

52 Rudo ND, Rosenberg IR, Wissler RW. The effect of partial starvation and glucagon treatment on intestinal villus morphology and cell migration. Proc Soc Exp Biol Med 1976; 152: 277-80.

53 Jacobs LR, Polak JM, Bloom SR, Dowling RA. Does enteroglucagon play a trophic role in intestinal adaptation? Clin Sci Mol Med 1976; 50: 14-5p.

54 Barros D'Sa AAB, Buchanan KD. Gastrin and glucagon responses to extensive distal small bowel resection: an experimental study in dogs. Eur Surg Res 1980; 12: 52-61.

55 Wright HK, Poskitt T, Cleveland JC, Herskovic T. The effect of total colectomy on morphology and absorptive capacity of ileum in rats. J Surg Res 1969; 9: 301-4.

56 Bucholz JW, Malamud D, Ross JS, Malt RA. Onset of cell proliferation in the shortened gut: growth after subtotal colectomy. Surgery 1976; 80: 601-7.

57 Masesa PC, Forrester JM. Consequences of partial and subtotal colectomy in the rat. Gut 1977 ; 18: 37-44.

58 Wright HK, Cleveland JC, Tilson MD, Herskovic T. 
Morphology and absorptive capacity of the ileum after ileostomy in man. Am J Surg 1969; 117: 242-5.

59 Besterman HS, Bloom SR, Christofides ND, Mallinson CN, Pera A, Modigliani R. Gut hormone profile in inflammatory bowel disease. Gut 1978; 19: A988-9.

60 Mayston PD, Barrowman JA, Dowling RH. Effect of pentagastrin on small bowel structure and function in the rat. Digestion 1975; 12: 78-84.

61 Oscarson JEA, Veen HF, Williamson RCN, Ross JS, Malt RA. Compensatory postresectional hyperplasia and starvation atrophy in small bowel: dissociation from endogenous gastrin levels. Gastroenterology 1977; 72: 890-5.

62 Morin CL, Ling V, Bourassa D. Effect of pentagastrin on the small intestine after resection. Gastroenterology 1977; 72: 1105.

63 Weser E. Role of gastrin in intestinal adaptation after small bowel resection. Gastroenterology 1978; 75: 323-4.

64 Christofides ND, Bloom SR. Motilin. In: Bloom SR, ed. Gut hormones vol 2. Edinburgh: Churchill Livingstone, 1981: 273-89.
65 Bloom SR, Christofides ND, Besterman HS. Raised motilin in diarrhoea. Gut 1978; 19: A959.

66 Greenberg GR, McCloy RF, Adrian TE. Inhibition of pancreas and gallbladder by pancreatic polypeptide. Lancet 1978; 2: 1280-2.

67 Adrian TE, Besterman HS, Mallinson CN, Greenberg GR, Bloom SR. Inhibition of secretin-stimulated pancreatic secretion by pancreatic polypeptide. Gut 1979; 20: 37-40.

68 Taylor IL, Solomon TE, Walsh JH, Grossman MI. Pancreatic polypeptide metabolism and effect on pancreatic secretion in dogs. Gastroenterology 1979; 76: 524-8.

69 Mitchenere P, Adrian TE, Kirk RM, Bloom SR. Effect of gut regulatory peptides on intestinal luminal fluid in the rat. Life Sci 1981; 29: 1563-70.

70 Lin T-M, Evans DC, Shaar CJ, Chance RE. Physiological versus pharmacological actions of bovine pancreatic polypeptide (BPP) on the pancreas, stomach, gallbladder, choledochal sphincter and intestine of dogs. In: Miyoshi A, ed. Gut peptides. Amsterdam: Elsevier, 1980: 175-81. 